\title{
The Importance of the Microbiological Quality of Ready-to-Eat Salads from a Public Health Perspective
}

\section{Coniglio $\mathbf{M A}^{*}$, Faro $\mathbf{G}$ and Marranzano $\mathbf{M}$}

Department of Medical, Surgical Sciences and Advanced Technologies, GF Ingrassia University of Catania, Italy

\begin{abstract}
The microbiological quality of marketable ready-to-eat (RTE) salads was discussed in terms of Public Health concerns. Since RTE foods are edible without additional treatment, risks of foodborne outbreaks may be high. The initial quality and subsequent handling of these products appear to influence their microbiological safety and shelf life. The authors evaluated the microbiological quality of marketable RTE salads. A total of 100 samples of RTE mixed salads were collected from local supermarkets in Catania (Italy). The RTE packages were immediately transported to the laboratory and analyzed according to the international standard methods (ISO) for aerobic mesophilic count (AMC at $30^{\circ} \mathrm{C}$ ), Escherichia coli, coliforms, Salmonella and Listeria monocytogenes. All the samples (100\%) were positive for AMC (median concentrations $10^{6}-10^{7} \mathrm{CFU} / \mathrm{g}$ ), $25.00 \%$ were positive for coliforms (median concentrations $10^{4}-10^{5} \mathrm{CFU} / \mathrm{g}$ ) and $10.00 \%$ for $\mathrm{E}$. coli (median concentrations $<10^{2} \mathrm{CFU} / \mathrm{g}$ ). No sample was positive for Salmonella and Listeria monocytogenes. Some questions were analyzed in response to possible Public Health concerns with regard to the nature and safety of RTE foods. People could benefit enormously from RTE salads thanks to the increase in minerals and fibers uptake and, in turn, the prevention of some chronic diseases in the general population. Anyway, there is the need to examine the potential negative effects on human health of the consumption of these products.
\end{abstract}

Keywords: Ready-to-eat foods; Fruits and vegetables; Microbiological quality; Human health

\section{Introduction}

In industrialized countries major causes of morbidity and mortality are related to poor diet and a sedentary lifestyle. In particular, cardiovascular disease, hypertension, type 2 diabetes, stroke, and certain cancers (i.e., colon rectum) are specifically linked to poor diet and physical inactivity. Moreover, an energy imbalance (more calories consumed than expended) is the most important factor contributing to the increase in overweight and obesity which, in turn, are major risk factors for certain chronic diseases such as type-2 diabetes[1].

The association between increased intake of vegetables and reduced risk of chronic diseases is variable and depends on the specific disease [2] Anyway, given the mounting evidence suggestive of a potential benefit, recommendations for the consumption of fruits and vegetables are always issued by the nutrition guidelines. However, to translate these guidelines into daily life is not simple. In fact, there are some important aspects that may affect food choices, such as financial resources and available household members' skills in food acquisition, as well as feelings of time scarcity [3]. In particular, especially in industrialized countries, people tend to adopt a more time-saving behavior in relation to daily food consumption and it has been observed that women's time routinely spent in food preparation declined in the last years [4]. This social trend has resulted in a growth of the market for fresh ready-toeat (RTE) foods, including RTE fruit and vegetables [5,6].

These products receive some degree of minimal technological processing before commercial distribution, but the processing in most cases is inadequate in ensuring their microbiological safety. In this study the microbiological quality of marketable RTE salads was evaluated. The microbiological quality of marketable RTE salads was discussed in terms of Public Health concerns.

\section{Methods}

During the second semester of 2014 a total of 100 samples of RTE mixed salads (endive, rocket, lettuce and red chicory) were collected from local supermarkets in Catania (Italy). The RTE packages were immediately transported to the laboratory and analyzed according to the International Standard Methods (ISO) for aerobic mesophilic count [7] (AMC at $\left.30^{\circ} \mathrm{C}\right)$, Escherichia coli [8], coliforms [9], Salmonella [10] and Listeria monocytogenes [11].

\section{Results and Discussion}

As shown in Table 1, of the 100 RTE salads analyzed no sample was positive for Salmonella and Listeria monocytogenes, all the samples $(100 \%)$ were positive for AMC (median concentrations $10^{6}-10^{7} \mathrm{CFU} / \mathrm{g}$ ), while $25(25.00 \%)$ were positive for coliforms (median concentrations $10^{4}-10^{5} \mathrm{CFU} / \mathrm{g}$ ) and $10(10.00 \%)$ for $\mathrm{E}$. coli (median concentrations $\left.<10^{2} \mathrm{CFU} / \mathrm{g}\right)$.

Taking into consideration the Regulation (EC) No 1441/2007 [12] concerning the microbiological criteria of foodstuffs, the absence of

\begin{tabular}{|c|c|c|c|}
\hline $\begin{array}{c}\text { Microbiological } \\
\text { test }\end{array}$ & $\begin{array}{c}\text { No. of sample } \\
\text { units }\end{array}$ & $\begin{array}{c}\text { Percentage (\%) of } \\
\text { positive samples }\end{array}$ & $\begin{array}{c}\text { Median concentrations } \\
\text { (CFU/g) }\end{array}$ \\
\hline AMC & 100 & 100 & $10^{6}-10^{7}$ \\
\hline Coliforms count & 100 & 25 & $10^{4}-10^{5}$ \\
\hline E. coli count & 100 & 10 & $<10^{2}$ \\
\hline Salmonella count & 100 & ND & - \\
\hline $\begin{array}{c}\text { L. monocytogenes } \\
\text { count }\end{array}$ & 100 & ND & - \\
\hline ND: Not detected in 25g. & & \\
\hline
\end{tabular}

Table 1: AMC, coliforms and Escherichia coli counts, and Salmonella and Listeria monocytogenes detection in the samples analyzed.

*Corresponding author: Coniglio MA, Department of Medical, Surgical Sciences and Advanced Technologies, GF Ingrassia, University of Catania, via Santa Sofia 87 95123, Catania, Italy, Tel. +39-0953782087; E-mail: ma.coniglio@unict.it

Received March 15, 2016; Accepted April 05, 2016; Published April 13, 2016

Citation: Coniglio MA, Faro G, Marranzano M (2016) The Importance of the Microbiological Quality of Ready-to-Eat Salads from a Public Health Perspective. J Food Process Technol 7: 577. doi:10.4172/2157-7110.1000577

Copyright: (c) 2016 Coniglio MA, et al. This is an open-access article distributed under the terms of the Creative Commons Attribution License, which permits unrestricted use, distribution, and reproduction in any medium, provided the original author and source are credited. 
Salmonella and Listeria monocytogenes clearly indicates the safety for consumers of the RTE salads analyzed. Moreover, the E. coli median concentrations lower than the value allowed by the EC Regulation $\left(<10^{2}\right.$ $\mathrm{CFU} / \mathrm{g}$ ), indicates the satisfactory sanitary conditions of the samples considered for the study. In fact, it has been shown that E. coli may have a good correlation with potential contamination by enteric pathogens [13]. On the contrary, the high levels of AMC and coliforms may indicate the lack of good practices during manipulation, which may also contribute for decreasing the shelf life of products. Anyway, upon subjective visual and olfactory inspection, all the samples analyzed in the present work appeared to be suitable for consumption.

On the basis of the results showed above, some questions may be raised in response to possible Public Health concerns with regard to the nature and safety of RTE foods.

First of all: 'What are RTE foods?' RTE foods are defined as foods that can be consumed immediately at the point of sale without further preparation or treatment [14]. This definition is directly linked to the second question: 'Are RTE foods safe for the consumers?'. Since RTE foods are edible without additional treatment, it has been underlined that risks of foodborne outbreaks may be high [15-18]. In particular, the initial quality and subsequent handling of these products appear to influence their microbiological safety and shelf life $[6,19]$. Although no sample analyzed in our study showed the presence of pathogens, the high levels of AMC and coliforms may indicate the lack of good practices during manipulation, including poor agricultural water quality, as well as the incorrect application of Good Manufacturing Practice (GMP) and Hazard Analysis and Critical Control Point (HACCP) systems during production, processing, packaging and distribution [20]. For this reason, control of microbiological contamination is critical to ensure the safety of these products.

This consideration pose a third question: 'How are RTE salads/ vegetables regulated in EU?'. In 2005, the EC Regulation no.1441/2007 amending EC Regulation no. 2073/2005 [12] indicates the recovery of $E$. coli in RTE vegetables as an index of the hygienic process, and Salmonella spp. and Listeria monocytogenes as an index of safety. Although at the moment there are no mandatory microbiological criteria which include reference limits for AMC, this parameter could represent a useful tool to evaluate the microbiological quality of the production processes [21]. In this study, the high levels of AMC and coliforms could indicate the need of more rigorous risk assessment techniques and of recommending the correct assessments.-

One of the objectives of the EU is to consider consumers the key stakeholders in the total food/feed chain. Understanding the attitudes and beliefs of European consumers in relation to food and nutrition is vital to address population health concerns, as well as to develop targeted communication strategies in order to promote the adoption of healthy diets and maintain well-being through an optimal nutritional intake [22]. This objective may raise a fourth question: 'Why are RTE foods produced if they are considered risk foods?'. The answer is that RTE foods are developed and marketed because there is some perceived advantage to the consumer of these foods. Good nutrition is vital to good health and is absolutely essential to achieve and maintain a body weight that optimizes health. Vegetables, in particular, are considered essential in a balanced diet as part of the Mediterranean diet and their health benefits in reducing the risk for chronic diseases should be considered in the context of an overall healthy diet. Taking into consideration the changes in consumers' food choices related to their daily lifestyle, advanced food processing technologies and novel packaging schemes can help 'healthy' foods, such as vegetables, to stay competitive in the global market. In Italy, for example, between January and October 2010, consumption of whole fruits and vegetables decreased by $0.8 \%$, while an $8.3 \%$ increase in the consumption of RTE vegetables was observed in the same period of time [23]. The high median concentrations of AMC $\left(10^{6}-10^{7} \mathrm{CFU} / \mathrm{g}\right)$ and coliforms $\left(10^{4}\right.$ $10^{5} \mathrm{CFU} / \mathrm{g}$ ) recovered in all the samples analyzed in our study, did not correlate with the presence of E. coli, which was lower than $10^{2} \mathrm{CFU} / \mathrm{g}$ or Salmonella and Listeria monocytogenes, which were absent in all the samples. This data may indicate that RTE salads can be considered safe for the consumers.

Thus, the fifth question is: 'What are the main issues of concern for human health linked to the microbiological quality of RTE salads?'. The three main issues debated are (i) responsibility in foodborne outbreaks, (ii) contribution to the antibiotic resistance genes transfer and (iii) exposition of the consumers to disinfection by-products (DBPs) due to their decontamination.

For what concern the first issue, it is noteworthy that various foodborne pathogens associated with RTE foods have been found to contribute to foodborne outbreaks $[17,18]$. As already discussed, methods of storage, processing, handling, and display can affect the levels of microorganisms in these products $[16,24]$. Fresh vegetables, in particular, have become increasingly recognized as potential vehicles of foodborne diseases, which are stressed by international outbreaks such as the associated with the fenugreek seed sprouts contaminated with $E$. coli O104:H4 in 2011 in Europe, and tomato and spinach with Salmonella and E. coli O157 in the USA [6,25]. Thus, monitoring of the level of bacteria in RTE salads/vegetables is important to ensure the safety of this type of high-risk foods, and food quality and safety research should always be directed to strategies for preventing the spread of biological hazards along the entire food chain. The second issue refers to the role of food in human exposure to antimicrobial resistant bacteria. As far as we know, the contribution of minimally processed vegetables for the spread of antibiotic resistance remains unclear and has been scarcely considered in surveillance studies. Nevertheless, there is evidence that RTE salads may be vehicles for antibiotic resistance bacteria/genes with clinical interest [26]. Thus, contamination during preparation, handling and processing of salads, should be considered also in the light of exposure to pathogens and/or commensal and environmental bacteria as a reservoir of resistance genes. Finally, there are no strategies able to achieve the complete elimination of hazardous microorganisms on RTE salads without affecting their quality [27]. Decontamination of fresh vegetables is generally based on the application of chlorine. Nonetheless, hyperchlorination of process wash water with high load of organic material may produce unacceptably high levels of trihalomethanes (THMs) and other carcinogenic DBPs [28,29]. For this reason, the industrial demand for natural alternative disinfectants should be encouraged [30,31].

Finally, the last question is: 'What should the scientific community do to improve the evaluation of RTE salads?'. From our point of view, taking into account our results, the scientific community should take an active role in relation to RTE salads, primarily for two main reasons: (1) Public Health could benefit enormously from these products thanks to the increase in minerals and fibers uptake and, in turn, the prevention of some chronic diseases in the general population; and (2) the need to examine the potential negative effects on human health of the consumption of these products.

\section{Conclusion}

In conclusion, the present study suggests that evaluations on RTE 
Citation: Coniglio MA, Faro G, Marranzano M (2016) The Importance of the Microbiological Quality of Ready-to-Eat Salads from a Public Health Perspective. J Food Process Technol 7: 577. doi:10.4172/2157-7110.1000577

products must be holistic and should consider not only safety but also food security, as well as social aspects linked to nutrition and health education.

\section{References}

1. Steffen LM (2006) Eat your fruit and vegetables. Lancet 367: 278-279.

2. Bazzano LA (2006) The high cost of not consuming fruits and vegetables. J Am Diet Assoc 106: 1364-1368.

3. Zuzanek J, Becker T, Peters P (1998) The harried leisure class revisited: Dutch and Canadian trends in the use of time from the 1970s to the 1990s. Leisure Stud 17: 1-19.

4. Jabs J, Devine CM (2006) Time scarcity and food choices: an overview. Appetite 47: 196-204

5. Little CL, Gillespie IA (2008) Prepared salads and public health. J Appl Microbiol 105: 1729-1743.

6. Olaimat AN, Holley RA (2012) Factors influencing the microbial safety of fresh produce: a review. Food Microbiol 32: 1-19.

7. (2016) Matrix extension study: validation of the compact dry TC method for enumeration of total aerobic bacteria in selected foods. J AOAC Int

8. (2016) matrix extension study: Validation of the compact dry EC method for enumeration of Escherichia coli and non-E. coli coliform bacteria in selected foods. J AOAC Int .

9. ISO 4832:1991 Microbiology general guidance for the enumeration of coliforms colony count technique.

10. ISO $6579: 2002$ Microbiology of food and animal feeding stuffs horizontal method for the detection of Salmonella spp.

11. Scotter SL, Langton S, Lombard B, Lahellec C, Schulten S, et al. (2001) Validation of ISO method 11290 part 2. Enumeration of Listeria monocytogenes in foods. Int J Food Microbiol 70: 121-129.

12. (2007) Commission Regulation (EC) No 1441/2007 of 5 December amending Regulation (EC) No 2073/2005 on microbiological criteria for foodstuffs. Official Journal of the European Union.

13. Doyle MP, Erickson MC (2006) Closing the door on the fecal coliform assay. Microbe 1: 162-163.

14. US Food and Drug Administration. Analysis and evaluation of preventive control measures for the control and reduction/ elimination of microbial hazards on fresh and fresh-cut produce.

15. Abadias M, Usall J, Anguera M, Solsona C, Viñas I (2008) Microbiological quality of fresh, minimally-processed fruit and vegetables, and sprouts from retail establishments. Int J Food Microbiol 123: 121-129.

16. Christison CA, Lindsay D, von Holy A (2008) Microbiological survey of ready to-eat foods and associated preparation surfaces in retail delicatessens Johannesburg South Africa. Food Control 19: 727-733.
17. Castro-Rosas J, Cerna-Cortés JF, Méndez-Reyes E, Lopez-Hernandez D, Gómez-Aldapa CA, et al. (2012) Presence of faecal coliforms Escherichia col and diarrheagenic $E$. coli pathotypes in ready-to-eat salads from an area where crops are irrigated with untreated sewage water. Int J Food Microbiol 156 176-180.

18. Seow J, Ágoston R, Phua L, Yuk HG (2012) Microbiological quality of fresh vegetables and fruits sold in Singapore. Food Control 25: 39- 44.

19. (2009) CDC Centers for Disease Control and Prevention Investigation update: outbreak of Salmonella Typhimurium infections.

20. Karagozlu N, Ergonul B, Ozcan D (2011) Determination of antimicrobial effect of mint and basil essential oils on survival of E. coli $\mathrm{O} 157: \mathrm{H} 7$ and S. typhimurium in fresh-cut lettuce and purslane. Food Control 22: 1851-1855.

21. MD 22 mars (1993) Règles d'hygiène applicables aux végéteaux et preparation de végéteaux crus préts à l'emploi à la consumation humaine. Official $\mathrm{J} \mathrm{Fr}$ Repbl.

22. European Commission. FP7 Research and Innovation.

23. (2010) Italy Istituto di Servizi per il Mercato Agricolo Alimentare (ISMEA). Le tendenze degli acquisti domestici agroalimentari. Trends in produce market for domestic consumption.

24. Fang TJ, Wei QK, Liao CW, Hung MJ, Wang TH (2003) Microbiological quality of 18 degrees $C$ ready-to-eat food products sold in Taiwan. Int J Food Microbio 80: $241-250$

25. (2013) European Food Safety Authority (EFSA) and Austrian Institute of Technology (AIT) GmbH. Food of plant origin production methods and microbiological hazards linked to food-borne disease.

26. Campos J, Mourão J, Pestana N, Peixe L, Novais C, et al. (2013) Microbiologica quality of ready-to-eat salads: an underestimated vehicle of bacteria and clinically relevant antibiotic resistance genes. Int J Food Microbiol 166 464-470.

27. USFDA (United States Food and Drug Administration). Food code 2009.

28. Fawell J (2000) Risk assessment case study-chloroform and related substances. Food Chem Toxicol 38: S91-95.

29. Gil MI, Selma MV, López-Gálvez F, Allende A (2009) Fresh-cut product sanitation and wash water disinfection: problems and solutions. Int $\mathrm{J}$ Food Microbiol 134: 37-45

30. Wentao X, Wei Q, Kunlun H, Feng G, Jiajia Y et al. (2007) Antibacterial effect of grapefruit seed extract on food-borne pathogens and its application in the preservation of minimally processed vegetables. Postharvest Bio Tec. 45:126-133

31. Gutierrez J, Bourke P, Lonchamp J, Barry-Ryan C (2009) Impact of plan essential oils on microbiological organoleptic and quality markers of minimally processed vegetables. Innovative Food Sci Emerg Technol 10: 195-202. 